\title{
Improved multiplex PCR method for the detection of diverse Megalocytivirus in the Korea
}

\author{
Han Chang Sohn ${ }^{1}$, Seongdo Lee ${ }^{2}$, Mun Gyeong Kwon ${ }^{3}$, Jee Youn Hwang ${ }^{3}$, Seong Don \\ Hwang $^{3}$, and Jehee Lee ${ }^{1}$ \\ ${ }^{1}$ Jeju National University \\ ${ }^{2}$ National Fishery Products Quality Management Service \\ ${ }^{3}$ National Institute of Fisheries Science
}

February 5, 2021

\begin{abstract}
Megalocytivirus is a genus of piscine viruses that belongs to the Iridoviridae family, and this family comprises red seabream iridovirus (RSIV), turbot reddish body iridovirus (TRBIV), and infectious spleen and kidney necrosis virus. RSIV causes high mortality and economic losses in the rock bream (Oplegnathus fasciatus) Korean aquaculture industry. The World Organization for Animal Health's Office International des Epizooties has provided a manual for RSIV detection. However, detection against TRBIV has not been confirmed. In this study, a multiplex PCR method was established to detect two genotypes of Megalocytivirus, RSIV and TRBIV. New primer pairs were optimized for the PCR reaction. A mixture of one universal and two specific primer pairs could amplify three distinct products targeting three different genes. The sensitivity of the primer pairs was evaluated and results showed a detection limit of 2.0 ? 105 copies for each target gene. Moreover, the primer pairs did not amplify any other viruses. The evaluation of multiplex PCR using 21 RSIV Korean isolates has shown that it can distinguish two genotypes of Megalocytivirus from 21 RSIV Korean isolates. Finally, we describe a new multiplex PCR method to detect different genotypes of Megalocytivirus simultaneously, which makes the diagnosis of viral diseases occurring in the Korean aquaculture industry more convenient.
\end{abstract}

Improved multiplex PCR method for the detection of diverseMegalocytivirus in the Korea

Hanchang Sohn ${ }^{1,2}$, Seongdo Lee ${ }^{3}$, Mun Gyeong Kwon ${ }^{4}$, Jee Youn Hwang ${ }^{4}$, Seong Don Hwang ${ }^{5^{*}}$ and Jehee $\operatorname{Lee}^{1,2^{*}}$

${ }^{1}$ Department of Marine Life Sciences, Jeju National University, Jeju Self-Governing Province 63243, Republic of Korea

${ }^{2}$ Fish Vaccine Research Center, Jeju National University, Jeju Self-Governing Province 63243, Republic of Korea

${ }^{3}$ General Affairs Division, National Fishery Products Quality Management Service, Busan 49111, Republic of Korea

${ }^{4}$ Aquatic Disease Control Division, National Institute of Fisheries Science, 216 Gijanghaean-ro, Gijang-up, Busan 46083, Republic of Korea

${ }^{5}$ Pathology Division, National Institute of Fisheries Science, 216 Gijanghaean-ro, Gijang-up, Busan 46083, Republic of Korea

Email address: Hanchang Sohn:hcsohn2@gmail.com, Seongdo Lee:lsd0081@korea.kr, Mun Gyeong Kwon: mgkwon@korea.kr , Jee Youn Hwang: jinihwang@korea.kr 


\section{*Corresponding authors.}

Jehee Lee, Marine Molecular Genetics Lab, Department of Marine Life Sciences, College of Ocean Science, Jeju National University, 66 Jejudaehakno, Ara-Dong, Jeju 690-756, Republic of Korea; Email:jehee@jejunu.ac.kr

Seong Don Hwang, Pathology Division, National Institute of Fisheries Science, 216 Gijanghaean-ro, Gijangup, Busan 46083, Republic of Korea; E-mail: sdhwang@korea.kr

Summary

Megalocytivirus is a genus of piscine viruses that belongs to the Iridoviridae family, and this family comprises red seabream iridovirus (RSIV), turbot reddish body iridovirus (TRBIV), and infectious spleen and kidney necrosis virus. RSIV causes high mortality and economic losses in the rock bream (Oplegnathus fasciatus ) Korean aquaculture industry. The World Organization for Animal Health's Office International des Epizooties has provided a manual for RSIV detection. However, detection against TRBIV has not been confirmed. In this study, a multiplex PCR method was established to detect two genotypes ofMegalocytivirus, RSIV and TRBIV. New primer pairs were optimized for the PCR reaction. A mixture of one universal and two specific primer pairs could amplify three distinct products targeting three different genes. The sensitivity of the primer pairs was evaluated and results showed a detection limit of $2.0 \times 10^{5}$ copies for each target gene. Moreover, the primer pairs did not amplify any other viruses. The evaluation of multiplex PCR using 21 RSIV Korean isolates has shown that it can distinguish two genotypes ofMegalocytivirus from 21 RSIV Korean isolates. Finally, we describe a new multiplex PCR method to detect different genotypes of Megalocytivirus simultaneously, which makes the diagnosis of viral diseases occurring in the Korean aquaculture industry more convenient.

Keywords: Megalocytivirus, Red sea bream iridovirus, Turbot reddish body iridovirus, Multiplex polymerase chain reaction.

\section{Introduction}

The family Iridoviridae comprises five genera, includingIridovirus , Chloriridovirus, Ranavirus ,Lymphocystivirus, and Megalocytivirus (Kurita and Nakajima, 2012). Among these genera, Megalocytivirus has been recently identified. It is an icosahedral double-strand DNA virus 120-240 nm in diameter (Sulistiyono et al., 2019).Megalocytivirus species are subdivided into three genotypes based on the major capsid protein (MCP) and ATPase as follows: (1) infectious spleen and kidney necrosis virus (ISKNV); (2) red sea bream iridovirus (RSIV); (3) turbot reddish body iridovirus (TRBIV) (Subramaniam et al., 2012). These viruses are known to cause massive mortality and economic losses in the aquaculture industry. RSIV is a causative agent of the RSIV disease, which was first reported in Japan in 1992 (Inouye et al., 1992). Approximately 40 species of marine and freshwater fish are susceptible to RSIV (Subramaniam et al., 2012), and infected fish show lethargy, anemia, petechiae in the gills, and enlargement of the spleen (Kawato et al., 2017). TRBIV is another piscine iridovirus which caused up to $40 \%$ mortality of cultured turbot (Scophthalmus maximus ) in China in 2004 (Shi et al., 2004; Zhang et al., 2009). However, recently, other flatfish species were also found to be susceptible to TRBIV (Jeong et al., 2005; Won et al., 2013)

Rock bream and olive flounder (Paralichthys olivaceus ) are predominant cultured aquaculture finfish species with high economic value in South Korea (Kim et al., 2002; Kim et al., 2006). The large-scale commercial aquaculture of these two species in South Korea was initiated in the 1980s. Since then, this industry has struggled with viral, bacterial, and parasitic diseases, which cause significant economic losses (Park et al., 2012). A report of RSIV infection in South Korea was published in 2000 (Jung and Oh, 2000). Further, the virus is known to cause mortality of up to $60 \%$ of cultured rock bream in South Korea (Sohn et al., 2000; Kim et al., 2002).

Polymerase chain reaction (PCR) has been used as a fundamental method in disease diagnostics. Moreover, it has become a potent tool in identifying a variety of organisms, which act as causative agents of diseases. The World Organization for Animal Health's Office International des Epizooties (OIE) has described a standard 
diagnostic method for RSIV detection based on antibody-based antigen methods (Kawato et al., 2017). A PCR-based detection method was described in 1998, and it has been used for the specific detection of the RSIV and ISKNV genotypes (Kurita et al., 1998). However, the current primer set of the OIE has not confirmed the specific detection of the TRBIV genotype. TRBIV infection has increased in recent decades in South Korea (Park et al., 2012; Won et al., 2013; Jung et al., 2016; Jin et al., 2018). Therefore, a suitable PCR-based detection method is essential for TRBIV detection.

Based on this, the nucleotide sequences of RSIV genes were compared between the Korean isolate of RSIV and other RSIV genotypes. Multiplex PCR primer sets were designed based on the specific genes of RSIV to detect and distinguish the genotypes of RSIV without sequencing. The newly designed multiplex PCR can discriminate among different genotypes of Megalocytivirus that can infect rock bream and olive flounder. Moreover, specificity and sensitivity assays were performed to determine the efficiency of the multiplex PCR.

lsout

2. Materials and methods

2.1 Virus samples

The fish species in Table 1 showing positive signs ofMegalocytivirus infection were collected from fish farms located in the specific regions of South Korea from 2012 to 2018. The spleen and kidney samples were isolated from the collected fish. Sampling was performed according to the Aquatic Disease Control Act in Korea. Tissue samples were snap-frozen and transported to the National Institute of Fisheries Sciences (NIFS), and Megalocytivirus infection was confirmed using the PCR method provided by OIE (Kawato et al., 2017). The virus was cultured using the method described in our previous study (Lee et al., 2020).

2.2 Primer design for the sequencing of RSIV genes

The full-length genomic sequences of RSIV isolates, including genotypes large yellow croaker iridovirus (LYCIV), orange-spotted grouper iridovirus (OSGIV), giant seapearch iridovirus (GSIV), RBIV-TY1, RBIV-C1, RSIV, RSIV Ehime-1, and TRBIV were obtained from GenBank (Accession number: AY532606, KC244182, AY894343, KT804738, AB104413, BC143114, AY779031, GQ273492) and aligned using the CLC Main Workbench software (Version 8.1, Qiagen, Germany). Primers were designed based on the following specific genes in the RSIV genomic sequence: ATPase, DNA polymerase (DPO), LRP 16 like protein, and Laminin EGF (Table 2) (Kurita et al., 2002). All nucleotide sequences of the designed primers were analyzed using NCBI BLAST to confirm specificity.

2.3 Multiplex PCR with the newly designed primers

Multiplex PCR was performed in $30-\mu \mathrm{L}$ reaction mixtures containing $0.3 \mu \mathrm{L}$ of $2.5 \mathrm{U}$ of Taq polymerase, 3 $\mu \mathrm{L}$ of 10X Taq reaction buffer, $2.5 \mu \mathrm{L}$ of $2.5 \mathrm{mM}$ dNTPs (Geneall, Korea), $2 \mu \mathrm{L}$ of gDNA, and a combination of 10 pmol of Meg-Univ and FLIV-specific and RSIV-specific primers. PCR conditions were as follows: 95 ${ }^{\circ} \mathrm{C}$ for $5 \mathrm{~min} ; 35$ cycles of $95{ }^{\circ} \mathrm{C}$ for $30 \mathrm{~s}, 60{ }^{\circ} \mathrm{C}$ for $30 \mathrm{~s}, 72{ }^{\circ} \mathrm{C}$ for $1 \mathrm{~min} ; 72{ }^{\circ} \mathrm{C}$ for 7 min. Next, amplified PCR products were separated by electrophoresis on $1.5 \%$ agarose gels, stained with ethidium bromide (Biosesang, Korea), and visualized using a UV gel documentation system (MDM instruments, Korea).

\subsection{Detection of RSIV in Korean samples based on the OIE manual and newly designed primers}

RSIV isolates collected from 2012 to 2018 were used to detect and differentiate the genotypes. In total, 21 isolates were collected, and the positive control RSIV-1/ RSIV-4 primers were obtained from NIFS. A plasmid construct was used as a positive control for the newly designed primers (Table 3).

\subsection{Sensitivity, specificity, and optimization of multiplex PCR}

Partial sequences of RSIV genes were cloned and used as double-stranded copies for quantification. Briefly, the same PCR condition was used for each primer set for the PCR amplification of the genes. PCR products were purified using the AccuPrep PCR Purification kit (Bioneer, Korea). The purified PCR products were 
ligated using T-vector pMD20 with the DNA Ligation kit Mighty Mix (TaKaRa, Japan) in a total volume of $10 \mu \mathrm{L}$ at $16^{\circ} \mathrm{C}$ for $30 \mathrm{~min}$. The ligated RSIV partial sequence/T-vector pMD20 construct was then transformed into Escherichia coli DH5 $\alpha$ cell at a 1:10 ratio. The recombinant plasmids were purified using the QIAfilter Plasmid Midi Kit (Qiagen). BamHI and EcoRI restriction enzymes were used to linearize the RSIV gene-recombinant $T$ vectors. The original plasmid was calculated based on the following copy numbers: ATPase, $2.88 \times 10^{10}$; LRP, $3.24 \times 10^{10}$; DPO, $3.26 \times 10^{10}$. Each plasmid was prepared in a 10 -fold serially diluted sample to assess the sensitivity of multiplex PCR. The specificity of multiplex PCR was tested using different virus samples, including spring viraemia of carp (SVC), infectious hematopoietic necrosis (IHN), viral hemorrhagic septicemia (VHS), viral encephalopathy and retinopathy (VER) and lymphocystis virus (LCDV).

To search for the appropriate PCR condition for the three sets of primers (Meg-Univ-F4, Meg-Univ-R4, FLIVF5, FLIV-R3, RSIV-F6, RSIV-R6), 11 primer combinations for concentration and 11 different annealing temperature conditions were used for optimization. Multiplex PCR was performed using a PCR mixture containing $0.3 \mu \mathrm{L}$ of $2.5 \mathrm{U}$ of Taq polymerase, $3 \mu \mathrm{L}$ of $10 \mathrm{X}$ Taq reaction buffer, $2.5 \mu \mathrm{L}$ of $2.5 \mathrm{mM}$ dNTPs, $2 \mu \mathrm{L}$ of gDNA, $30 \mathrm{pmol} / \mu \mathrm{L}, 20 \mathrm{pmol} / \mu \mathrm{L}, 15 \mathrm{pmol} / \mu \mathrm{L}, 10 \mathrm{pmol} / \mu \mathrm{L}$, and $5 \mathrm{pmol} / \mu \mathrm{L}$ of each primer, and nuclease-free water was added to a final volume of $30 \mu \mathrm{L}$. The PCR conditions were as follows: $95{ }^{\circ} \mathrm{C}$ for 5 min; 35 cycles of $95{ }^{\circ} \mathrm{C}$ for $30 \mathrm{~s}$, annealing at $50-70{ }^{\circ} \mathrm{C}$ (with an increase of $2^{\circ} \mathrm{C}$ per tested sample) for 30 $\mathrm{s}, 72{ }^{\circ} \mathrm{C}$ for $1 \mathrm{~min} ; 72{ }^{\circ} \mathrm{C}$ for $7 \mathrm{~min}$. PCR products were separated by agarose gel electrophoresis on $1.5 \%$ agarose gels stained with ethidium bromide and visualized using a UV gel documentation system.

3. Results

3.1 Diagnosis of RSIV from fish samples collected from Korean fish farms based on the OIE approach

Twenty Korean isolates could be diagnosed as RSIV genotypes based on the PCR method described in the OIE manual (Figure 1). Specific DNA fragments of 570 bp (RSIV-1) and 568 bp (RSIV-4) were amplified with the OIE primers. However, a single Korean isolate did not result in any amplicon (Figure 1).

3.2 Comparison of the nucleotide sequence of the RSIV and multiplex PCR primer region

Two sets of primers were proposed by the OIE manual (RSIV-1, RSIV-4). In the RSIV-1 primer set, TRBIV exhibited a five-nucleotide variation, whereas RBIV, GSIV, and OGSIV exhibited one-nucleotide variation in the forward primer. The reverse primer showed a one-nucleotide variation for RBIV-TY1, TRBIV, and ISKNV (Figure 2A). RSIV-4 primers had one common variation for all genotypes, whereas there were additional two variations for the ISKNV genotype in the reverse primers. In contrast, forward primers had 2-3-nucleotide variation for RBIV-TY1, TRBIV, and ISKNV (Figure 2B).

Mega-Univ primers, which targeted the ATPase gene, had no nucleotide variation in the primer region (Figure $3 \mathrm{~A})$. In the TRBIV-specific primer set, the forward primer had eight-nucleotide variation for all genotypes except for TRBIV and ISKNV (Figure 3B). Additionally, the reverse primer had the same variation as the forward primer for all genotypes, except ISKNV had an extra one-nucleotide variation. RSIV-specific primer sets showed the 2-4 variation in the forward and reverse primer regions. These variations were only observed in the TRBIV and ISKNV genotypes (Figure 3C).

\subsection{Evaluation of newly designed multiplex-PCR primers}

Three different genes were amplified from two differentMegalocytivirus genotypes using relevant sets of primers (Meg-Univ-F4/R4: 534 bp, TRBIV-specific-F/R: 401 bp, RSIV-specific-F/R: 245 bp). The amplified fragments were visualized using a 1.5\% agarose gel (Figure 4, Lanes 1-3). For the multiplex-PCR, three sets of primers showed the estimated size of the amplicon with each template. Moreover, no inhibitory activity was observed among the primers in terms of amplification (Figure 4, Lane 4-6).

\subsection{Sensitivity and specificity optimization of newly designed multiplex-PCR primers}

To determine the sensitivity of the multiplex PCR primers, PCR was performed with two conditions, single or triple sets of primers. PCR was performed using a 10-fold serial dilution of plasmid construct $\left(2.0 \times 10^{9}\right.$ to 
$2.0 \times 10^{1}$ per PCR reaction). The single primer sets were able to detect up to $2.0 \times 10^{3}, 2.0 \times 10^{3}$, and $2.0 \times$ $10^{5}$ copies of Meg-Univ, TRBIV-specific, and RSIV-specific products, respectively (Figure 5A-C). Multiplex PCR was able to detect up to $2.0 \times 10^{5}$ copies of each target template (Figure 5D-E). The specificity test also showed that the new multiplex primer set does not result in any amplicons of the expected size for the other virus strains used in the specificity optimization (Figure 6).

\subsection{Optimization of newly designed multiplex PCR primers}

As the primers were confirmed based on their sensitivity, primer optimization was performed to search for a suitable combination of primer concentration and annealing temperature. A gradient multiplex PCR was performed within a temperature range of $50^{\circ} \mathrm{C}$ to $70^{\circ} \mathrm{C}$. The primer combination Meg-Univ and TRBIVspecific did not show any difference for all the temperature ranges. However, for Meg-Univ and RSIV-specific, a non-specific amplicon was observed at $50,52,54.5$, and $55.8^{\circ} \mathrm{C}$ (Figure $7 \mathrm{~A}$ ). For the primer concentration, the primer mixture ratio of 30:10:10 resulted in the strongest amplicon. Lower concentration combinations resulted in weak amplicons (Figure 8).

\subsection{Evaluation of newly designed multiplex PCR using field samples}

The multiplex PCR was then employed using the field samples to validate the ability of the test to detect two genotypes ofMegalocytivirus. In total, 21 Korean Megalocytivirusisolates were used, and it was able to distinguish two genotypes. Among these 21 isolates, 20 were detected as the RSIV genotype, whereas one was detected as the TRBIV genotype (Figure 9). 4. Discussion

Numerous viral diseases, such as RSIV infection, VHS, VER, IHN, SVC, and LCDV have been reported as critically important in the South Korea aquaculture industry (Cho et al., 2010; Hossain et al., 2007; Kim et al., 2018; Oh et al., 2019). RSIV infection is a viral disease that causes massive mortality in rock bream mariculture. Recently, studies have reported the RSIV infection of turbot, olive flounder, and starry flounder (Takano et al., 2001; Shi et al., 2004; Jeong et al., 2005; Won et al., 2013; Jin et al., 2018).

PCR has been used as the most basic method to diagnose pathogens in a variety of fields (Hoffmann et al., 2009; Khot and Fredrick, 2009). Moreover, the multiplex PCR method has been standardized in diagnostics due to its ability to detect multiple targets (Balacs, 1997; Markoulatos et al., 2002), and it has further benefits of detecting multiple targets in one reaction mixture. However, particular factors, such as unbalanced intensity of amplicons and compatibility differences with each primer in the amplification performance must also be considered (Wei et al., 2008; Yao et al., 2014). The OIE has provided a method to diagnose viral diseases of aquatic animals (Kawato et al., 2017). It comprises a PCR method that can detect RSIV and ISKNV simultaneoussly and RSIV alone (Kurita et al., 1998; Kawato et al., 2017). However, TRBIV detection with the OIE methods had not previously been confirmed.

Sequence analysis of the OIE primer has shown a 1-5-base pair mismatch in the sequence of the forward primer compared to the TRBIV sequence (Figure 2). Mismatches in the 3'-terminus of the primer-template are known to result in a dramatic reduction in the efficiency of PCR (Kwok et al., 1990; Ayyadevara et al., 2000). The primer pair is an essential factor for detecting the specific target of interest. Further, specificity and sensitivity are the most important aspects when designing a primer pair (Dieffenbach et al., 1993). Based on previous studies, the sequence analysis of different genotypes was performed, and it was shown that the genotype TRBIV has a low identity compared to other genotypes (Supplementary table 1) (Kim et al., 2019; Oh et al., 2019). The new multiplex PCR primers were designed by selecting the gene with specific characteristics among the genotypes. Based on nucleotide identity analysis results, the Meg-Univ primer was designed for ATPase. The ATPase and MCP genes are well-conserved genes that have been used for phylogenetic studies of the Iridoviridae family (Song et al., 2008; Kim et al., 2019). Moreover, LRP and DPO are conserved genes in RSIV (Kurita et al., 2002). Based on the nucleotide analysis result, LRP and DPO were selected for the new primers (Supplementary table 1). The TRBIV genotype had the lowest identity for the LRP gene compared with that for the other genes. With this knowledge, primers were designed, and they showed specificity for the TRBIV gene. Further, the LRP gene was selected due to the difference in TRBIV and the conservation between the RSIV genotypes. We were able to design three sets of primers and 
successfully amplify targeting genes.

In this study, a multiplex PCR method was developed for the simultaneous detection of two genotypes of Megalocytivirus, combined with universal detection. In total, six individual primers were used to simultaneously amplify a band with a target size to conduct the multiplex PCR. To maximize the efficiency of annealing, multiple conditions of primer concentration and annealing temperature were tested, and a similar intensity was shown for most conditions. Thus, the optimum concentration and combination of primers was standardized as $30 \mathrm{pmol} / \mu \mathrm{L}$ for Meg-Univ, $10 \mathrm{pmol} / \mu \mathrm{L}$ for TRBIV-specific and $10 \mathrm{pmol} / \mu \mathrm{L}$ for RSIV-specific in the multiplex PCR (Figure 8, lane 1). The sensitivity of multiplex PCR compared to that of the uniplex PCR was approximately 100-fold lower for detection with Meg-Univ and TRBIV-specific primers. However, these RSIV-specific primers showed the same sensitivity against the template. With a lower detection limit of the multiplex PCR, similar results have been shown previously (Tuo et al., 2014; Yao et al., 2014). Our result indicated that primer pairs were successfully optimized and possess the capability to detect and differentiate between the two genotypes in a single reaction.

The newly developed method could distinguish RSIV and TRBIV from the 21 samples from South Korea. This method could thus be used to differentiate between TRBIV and RSIV, which was uncertain based on the OIE method. Furthermore, it enables the detection of the RSIV genotype in starry flounder (Platichthys stellatus ). A previous study has shown that starry flounder can be infected by Megalocytivirus, which belonged to the TRBIV type (Won et al., 2013; Kim et al., 2019). In our study, a sample from starry flounder resulted in an amplicon with the RSIV-specific primer. Megalocytivirus is known to have a wide range of susceptible species comprising freshwater and marine fish. Moreover, it is known to show pathogenicity regardless of the environment and species when it infects a susceptible host (Lee et al., 2020). Our result demonstrated a different Megalocytivirusinfection in starry flounder compared to that in previous reports (Park et al., 2012; Won et al., 2013; Jung et al., 2016; Jin et al., 2018). Thus, starry flounder can be considered to show susceptibility to the RSIV and TRBIV genotypes. In the present study, a new multiplex PCR method was developed, which is capable of diagnosing two different genotypes of Megalocytivirus with high sensitivity and specificity. This will provide a convenient and rapid method for the identification and verification of Megalocytivirus diagnosis in Korean aquaculture practices.

Acknowledgement

This research was supported by a grant from the National Institute of Fisheries Science (R2021071) and the Basic Science Research Program through the National Research Foundation of Korea (NRF) funded by the Ministry of Education (2019R1A6A1A03033553).

Ethics statement

The authors have confirmed the ethical policies of the journal, as described on the journal's author guideline page. No ethical approval was required as no laboratory animals were involved in this study.

Conflict of interest

The authors declare no conflict of interest.

\section{Reference}

Balacs, T., 1997: Multiplex PCR: Critical Parameters and Step-by-Step Protocol. Int. J. Aromather. 8, 43-45, DOI: 10.1525/jlca.1992.4.2.99.

Cho, M.Y., G.H. Park, B.Y. Jee, and J.W. Kim, 2010: Statistical data on fish virus of cultured olive flounder, Paralichthys olivaceusfrom 2005 to 2007. J. Fish Pathol . 23, 155-163.

Dieffenbach, C.W., T.M.J. Lowe, and G.S. Dveksler, 1993: General concepts for PCR primer design. Genome Res. 3, DOI: 10.1101/gr.3.3.S30.

Hoffmann, B., M. Beer, S.M. Reid, P. Mertens, C.A.L. Oura, P.A. van Rijn, M.J. Slomka, J. Banks, I.H. Brown, D.J. Alexander, and D.P. King, 2009: A review of RT-PCR technologies used in veterinary virol- 
ogy and disease control: Sensitive and specific diagnosis of five livestock diseases notifiable to the World Organisation for Animal Health. Vet. Microbiol. 139, 1-23, DOI: 10.1016/j.vetmic.2009.04.034.

Hossain, M., S.R. Kim, and M.J. Oh, 2007: The lymphocystis diseases in the Olive flounder, Paralichthys olivaceus . Univ. J. Zool. Rajshahi Univ. 26, 59-62, DOI: 10.3329/ujzru.v26i0.700.

Inouye, K., K. Yamano, Y. Maeno, K. Nakajima, M. Matsuoka, Y. Wada, and M. Sorimachi, 1992: Iridovirus Infection of Cultured Red Sea Bream,Pagrus major . Fish Pathol. 27, 19-27, DOI: 10.3147/jsfp.27.19.

Jeong, W. Do, J.C. Seung, S.K. Jong, J.A. Eun, S.L. Nam, J.C. Hee, H.L. Chan, S.P. Mi, W.K. Jin, C.K. Yi, and W.P. Jeong, 2005: Phylogenetic analysis of the major capsid protein gene of iridovirus isolates from cultured flounders Paralichthys olivaceus in Korea. Dis. Aquat. Organ. 64, 193-200.

Jung, S.J., and M.J. Oh, 2000: Iridovirus-like infection associated with high mortalities of striped beakperch, Oplegnathus fasciatus (Temminck et Schlegel), in southern coastal areas of the Korean peninsula.J. Fish Dis. 23, 223-226, DOI: 10.1046/j.1365-2761.2000.00212.x.

Jin, J.W., Y.K. Kim, S. Hong, Y.C. Kim, W.J. Kwon, and H. Do Jeong, 2018: Identification and Characterization of Megalocytivirus Type 3 Infection with Low Mortality in Starry Flounder, Platichthys stellatus , in Korea. J. World Aquac. Soc. 49, 229-239, DOI: 10.1111/jwas.12439.

Jung, M.H., J. Lee, and S.J. Jung, 2016: Low pathogenicity of flounder iridovirus (FLIV) and the absence of cross-protection between FLIV and rock bream iridovirus. J. Fish Dis. 39, 1325-1333, DOI: $10.1111 /$ jfd.12459.

Kawato, Y., J. Kurita, and K. Nakajima, 2017: Red sea bream iridoviral disease. Fish Pathol. 52, 57-62, DOI: $10.3147 /$ jsfp.52.57.

Kurita, J., K. Nakajima, I. Hirono, and T. Aoki, 2002: Complete genome sequencing of Red Sea Bream Iridovirus (RSIV). Fish. Sci. 68 (suppl)., 1113-1115.

Khot, P.D., and D.N. Fredrick, 2009: PCR-based diagnosis of human fungal infections. Expert Rev. Anti. Infect. Ther. 7, 1201-1221, DOI: 10.1586/ERI.09.104.

Kim, K. Il, E.S. Lee, J.W. Do, S.D. Hwang, M. Cho, S.H. Jung, B.Y. Jee, W.J. Kwon, and H. Do Jeong, 2019: Genetic diversity of Megalocytivirus from cultured fish in Korea. Aquaculture 509, 16-22, DOI: 10.1016/j.aquaculture.2019.05.014.

Kim, M.J., S. Lee, G.I. Godahewa, J.Y. Hwang, J.S. Seo, S.D. Hwang, and J. Lee, 2018: Complete genome sequence and phylogenetic analysis of spring viremia of carp virus isolated from leather carp (Cyprinus carpio nudus ) in Korea in 2016. Arch. Virol. 163, 2917-2919, DOI: 10.1007/s00705-018-3919-2.

Kim, J.W., S.H. Jung, M.A. Park, J. Do, D. Choi, B. Jee, M.Y. Cho, M.S. Kim, H. Choi, Y.C. Kim, M. Park, J.S. Lee, C. Lee, J.D. Bang, and J.S. Seo, 2006: Monitoring of Pathogens in Cultured Fish of Korea for the Summer Period from 2000 to 2006. J Fish Pathol. 3 , 207-214.

Kim, Y.J., S.J. Jung, T.J. Choi, H.R. Kim, K. V. Rajendran, and M.J. Oh, 2002: PCR amplification and sequence analysis of irido-like virus infecting fish in Korea. J. Fish Dis. 25, 121-124, DOI: 10.1046/j.13652761.2002.00345.x.

Kurita, J., and K. Nakajima, 2012: Megalocytiviruses .Viruses 4, 521-538, DOI: 10.3390/v4040521.

Kurita, J., K. Nakajima, I. Hirono, and T. Aoki, 1998: Polymerase Chain reaction (PCR) Amplification of DNA of Red Sea Bream Iridovirus.Fish Pathol. 33, 17-23.

Lee, E.S., M. Cho, E.Y. Min, S.H. Jung, and K. Il Kim, 2020: Novel peptide nucleic acid-based realtime PCR assay for detection and genotyping of Megalocytivirus . Aquaculture 518, 734818, DOI: 10.1016/j.aquaculture.2019.734818. 
Markoulatos, P., N. Siafakas, and M. Moncany, 2002: Multiplex polymerase chain reaction: A practical approach. J. Clin. Lab. Anal. 16, 47-51, DOI: 10.1002/jcla.2058.

Oh, W.T., J.W. Jun, S.S. Giri, S. Yun, H.J. Kim, S.G. Kim, S.W. Kim, S.J. Han, J. Kwon, and S.C. Park, 2019: Genome and phylogenetic analysis of infectious hematopoietic necrosis virus strain SNU1 isolated in Korea. Pathogens 8, 1-9, DOI: 10.3390/pathogens8040200.

Park, M.A., J.W. Do, M.S. Kim, S.R. Kim, M.G. Kwon, J.S. Seo, J. Song, and H.S. Choi, 2012: Comparison of pathogen detection from wild and cultured olive flounder, red sea bream, black sea bream and black rockfish in the coastal area of Korea in 2010. J. fish Pathol.25, 263-270, DOI: 10.7847/jfp.2012.25.3.263.

Shi, C., Y.G. Wang, S.L. Yang, J. Huang, and Q.Y. Wang, 2004: The first report of an iridoviruslike agent infection in farmed turbot,Scophthalmus maximus, in China. Aquaculture 236, 11-25, DOI: 10.1016/j.aquaculture.2003.11.004.

Sohn, S.G., D.L. Choi, J.W. Do, J.Y. Hwang, and J.W. Park, 2000: Mass Mortalities of Cultured Striped Beakperch , Oplegnathus fasciatus by Iridoviral Infection. J. fish Pathol. 13 , 121-127.

Song, J.Y., S.I. Kitamura, S.J. Jung, T. Miyadai, S. Tanaka, Y. Fukuda, S.-R. Kim, and M.J. Oh, 2008: Genetic variation and geographic distribution of Megalocytiviruses . J. Microbiol. 46, 29-33, DOI: 10.1007/s12275-007-0184-6.

Subramaniam, K., M. Shariff, A.R. Omar, and M. Hair-bejo, 2012:Megalocytivirus infection in fish. 221-233, DOI: $10.1111 / \mathrm{j} .1753-5131.2012 .01075 . x$.

Sulistiyono, D., S. Amanu, K. Imanudin, and Y.P. Kristianingrum, 2019: Rapid Diagnostic Test of Red Sea Bream Iridoviral Disease (RSIVD) in Grouper Epinephelus Sp. Based on Serological Co-Agglutination and Molecular Study. Mater. Sci. Forum 948, 95-100, DOI: 10.4028/www.scientific.net/msf.948.95.

Won, K.M., M.Y. Cho, M.A. Park, B.Y. Jee, J.I. Myeong, and J.W. Kim, 2013: The first report of a Megalocytivirus infection in farmed starry flounder, Platichthys stellatus, in Korea. Fish. Aquat. Sci. 16, 93-99, DOI: 10.5657/FAS.2013.0093.

Zhang, Q., C. Shi, J. Huang, K. Jia, X. Chen, and H. Liu, 2009: Rapid diagnosis of turbot reddish body iridovirus in turbot using the loop-mediated isothermal amplification method. J. Virol. Methods158, 18-23, DOI: $10.1016 /$ j.jviromet.2009.01.008.

Figure and table legends

Figure 1. Detection of Megalocytivirus Korean isolates using the diagnostic method according to the OIE manual. Lane M: marker, Lane 1-16, 17-21: Korean RSIV isolates, Lane 22: positive control, Lane N: negative control.

Figure 2. Comparison of the primer region for Megalocytivirusdetection using the CLC Main Workbench software (Ver. 8.1.0). Sequence variation in OIE primers (A, B). A red-dot box indicates the variation within the primer region.

Figure 3. Comparison of the primer region for Megalocytivirusdetection using the CLC Main Workbench software (Ver. 8.1.0). Sequence variation in Meg-Univ (A), TRBIV-specific (B), and RSIV-specific (C) primers. A red-dot box indicates the variation within the primer region. TRBIV, turbot reddish body iridovirus; RSIV, red seabream iridovirus.

Figure 4. Detection of two genotypes of Megalocytivirus according to the newly designed multiplex PCR primers using a plasmid construct. Lane 1: Meg-Univ, Lane 2: TBRIV-specific, Lane 3: RSIV-specific, Lane 4: Meg-Univ and TBRIV-specific, Lane 5: Meg-Univ and RSIV-specific, Lane 6: Meg-Univ, TBRIV specific, and RSIV specific. TRBIV, turbot reddish body iridovirus.

Figure 5. Detection of serially diluted samples of Megalocytivirus primers plasmid construct. Lane M: 100-bp marker, Lane 1-9: $2.0 \times 10^{9}-2.0 \times 10^{1}$ copy number plasmid, Lane N: negative control. (A) Serial dilution 
of Meg-Univ -specific, (B) serial dilution of TBRIV-specific, (C) serial dilution of RSIV-specific, (D) serial dilution of Meg-Univ and TBRIV-specific, (E) serial dilution of Meg-Univ and RSIV-specific. TRBIV, turbot reddish body iridovirus.

Figure 6. Specificity of diverse Megalocytivirus primers. (A) Specificity test of RSIV multiplex PCR primers using different virus strains. Lane M: marker, Lane 1-6: virus strains; 1: SVC; 2: VER; 3: VHS; 4: 4: IHN; 5: LCDV; 6: positive control (Meg-Univ+TRBIV-specific); 7: positive control (Meg-Univ+RSIV-specific), Lane N: negative control. (B) Specificity test of virus strains using specific primers of virus strains. Lane M: marker, Lane 16: virus strains; 1, 3, 5, 7, 9: LCDV, SVC, VER, VHS, IHN, respectively; Lane 2, 4, 6, 8, 10: Negative control for each virus strain. SVC, spring viraemia of carp; IHN, infectious hematopoietic necrosis; VHS, viral hemorrhagic septicemia; VER, viral encephalopathy and retinopathy; LCDV, lymphocystis virus; TRBIV, turbot reddish body iridovirus.

Figure 7. Optimization of the annealing temperature for multiplex PCR assay. (A) Meg-Univ (534 bp) and TBRIV-specific (451 bp), (B) Meg-Univ (534 bp) and RSIV-specific (245 bp). Lane M: marker, (1): $50^{\circ} \mathrm{C}$; (2): $52.0^{\circ} \mathrm{C}$; $(3): 54.5^{\circ} \mathrm{C} ;(4): 55.8^{\circ} \mathrm{C} ;(5): 58.4^{\circ} \mathrm{C} ;(6): 60.3^{\circ} \mathrm{C} ;(7): 62.2^{\circ} \mathrm{C} ;(8): 64.0^{\circ} \mathrm{C} ; 9: 65.9^{\circ} \mathrm{C} ; 10: 67.8^{\circ} \mathrm{C}$; 11: $70.2^{\circ} \mathrm{C}$. TRBIV, turbot reddish body iridovirus; RSIV, red seabream iridovirus.

Figure 8. Optimization of the primer concentration for multiplex PCR assay. (A) Meg-Univ (534 bp) and TBRIV-specific (451 bp), (B) Meg-Univ (534 bp) and RSIV-specific (245 bp). Lanes 1-11 indicate the concentration combination of three primers specific for Meg-Univ, TBRIV-specific, and RSIV-specific. (1) $30: 10: 10 \mathrm{pmol} / \mu \mathrm{L}$, (2) 20:10:10 pmol $/ \mu \mathrm{L}$, (3) 10:10:10 pmol $/ \mu \mathrm{L}$, (4) 30:20:10 pmol $/ \mu \mathrm{L}$, (5) 30:30:10 pmol/ $\mu \mathrm{L}$,

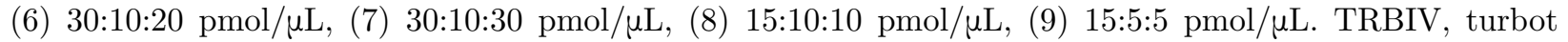
reddish body iridovirus; RSIV, red seabream iridovirus.

Figure 9. Detection of red seabream iridovirus (RSIV) Korean isolates using the newly designed multiplex PCR primers. Lane M: marker, Lane 1-16, 17-21: Korean RSIV isolates, Lane 22: positive control (MegUniv+TRBIV-specific), Lane 23: Meg-Univ+RSIV-specific), Lane N: negative control. TRBIV, turbot reddish body iridovirus.

Table 1. Megalocytivirus isolated from fish samples in Korea from 2012 to 2018 TRBIV, turbot reddish body iridovirus; RSIV, red seabream iridovirus.

Table 2. Primers used for nucleotide analysis of Megalocytivirusgenes RSIV, red seabream iridovirus.

Table 3. Primers used for Megalocytivirus detection RSIV, red seabream iridovirus; TRBIV, turbot reddish body iridovirus

Figures

Figure 1

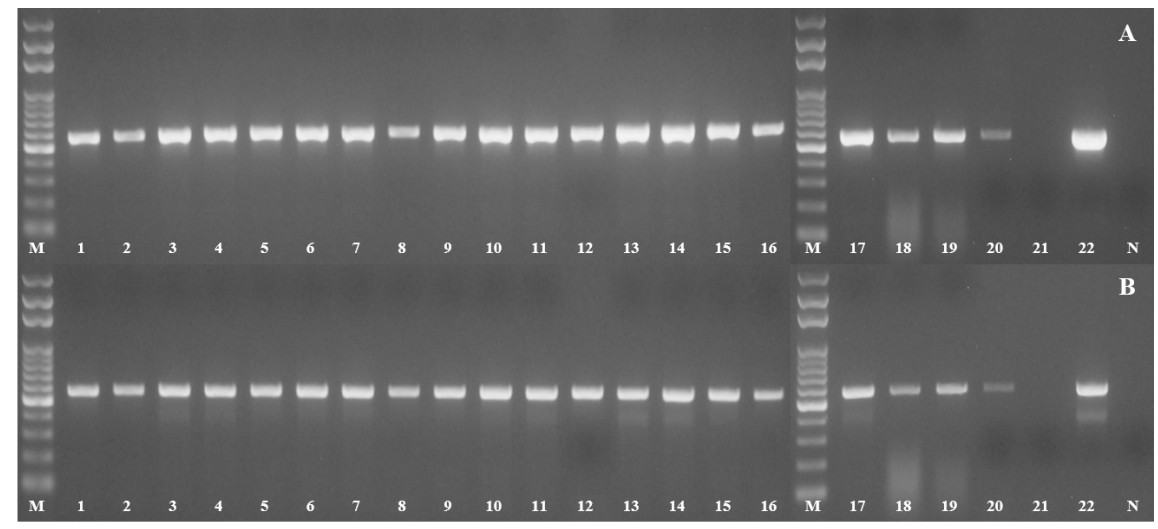


Figure 2

RSIV-1 (OIE) forward primer (5'-3')

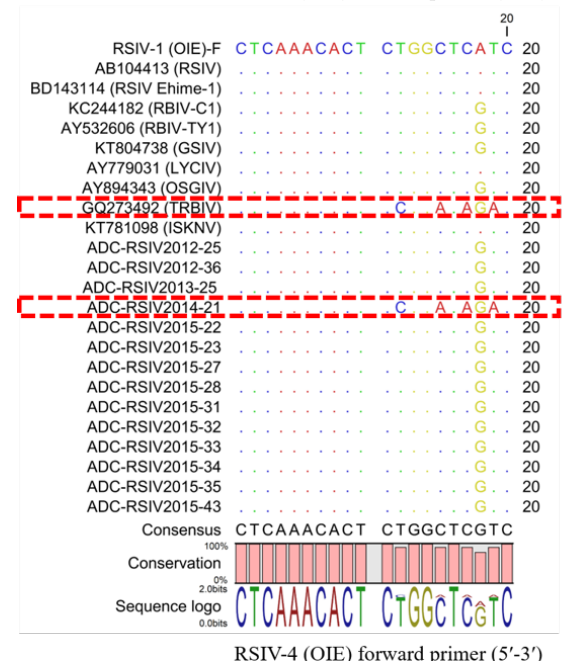

RSIV-4 (OIE) forward primer ( $\left.5^{\prime}-3^{\prime}\right)$

RSIV-4 (OIE)-F CGGGGGAAT GACGACTACA 20 RSIV-4 (OIE)-F CGGGGGCAAT GACGACTACA 20

KC244182 (RBIV-C)

KC244182 (RBIV-C1)

KT804738 (GSIV)

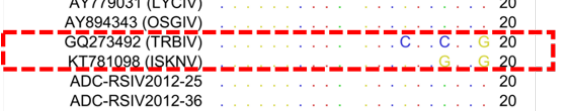

ADC-RSIV2012-36 20

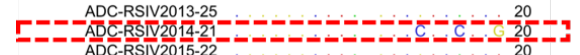

ADC-RSIV2015-23

ADC-RSIV2015-23

ADC-RSIV2015-28

ADC-RSIV2015-31

ADC-RSIV2015-33

ADC-RSIV2015-34

ADC-RSIV2015-35

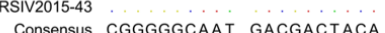

Conservation

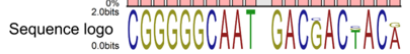

RSIV-1 (OIE) reverse primer $\left(5^{\prime}-3^{\prime}\right)$

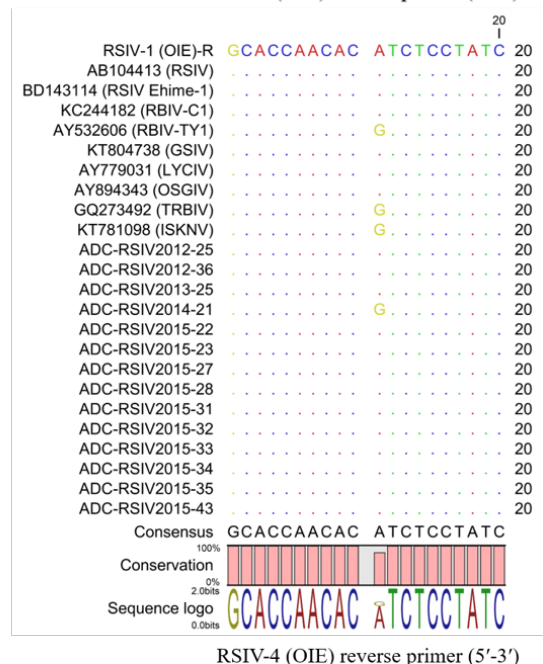

RSIV-4 (OIE)-R CCCCCTCTCC CTT RSIV-4 (OIE)-R CCGCCTGTGC CTTTTCTGGA 20
AB 104413 (RSIV) BD143114 (RSIV Ehime-1)

KC244182 (RBIV-C1)

KT804738 (GSIV)

AY7790031 (LYCIV)
AY894343 (OSGIV)

- GQ273492 (TRBIV) - -

A $-R$ SIV $2012-25$

ADC-RSIV2012-36

ADC-RSIV2013-25

ADC-RSIV2015-22

ADC-RSIV2015-23

ADC-RSIV2015-27

ADC-RSIV2015-28

ADC-RSIV2015-31

ADC-RSIV2015-33

ADC-RSIV2015-34

ADC-RSIV2015-35
ADC-RSIV2015-43

Consensus CCGCCTGTGC CTTTTGTGG

Consensus
Conservation
Com

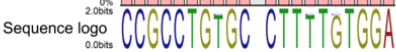

Figure 3 


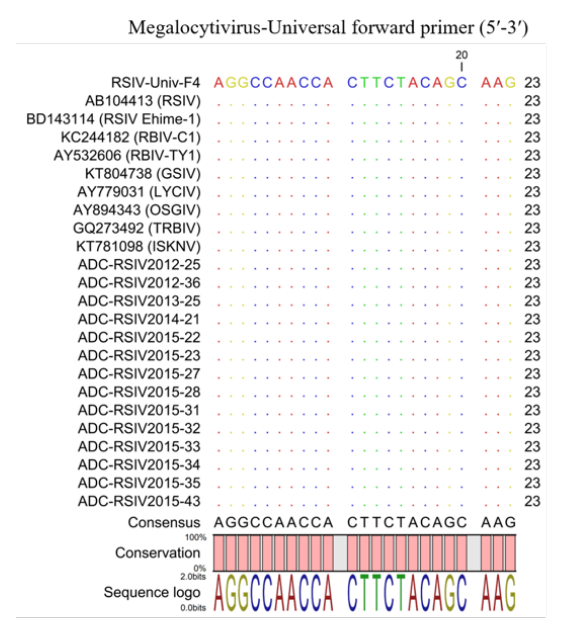

TRBIV-specific forward primer $\left(5^{\prime}-3^{\prime}\right)$

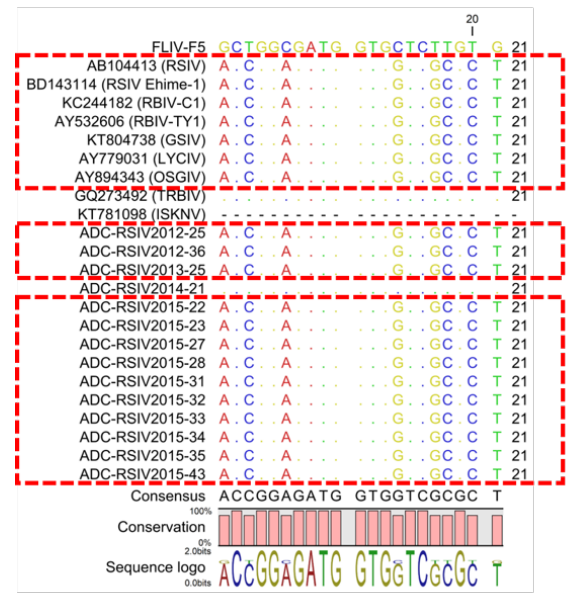

RSIV-specific forward primer $\left(5^{\prime}-3^{\prime}\right)$

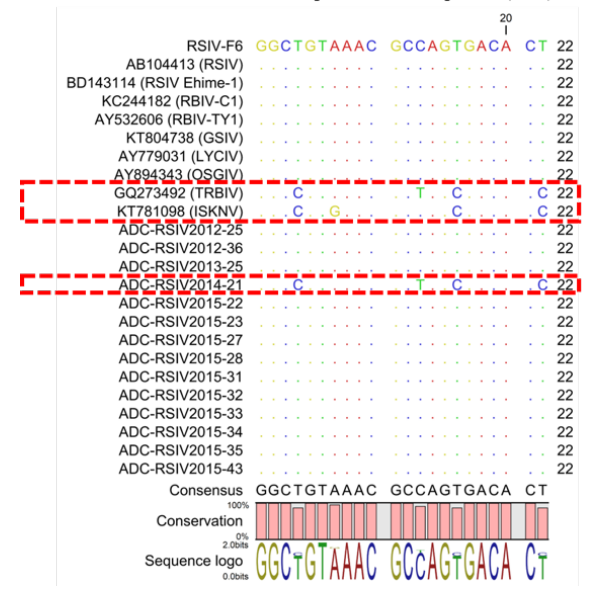

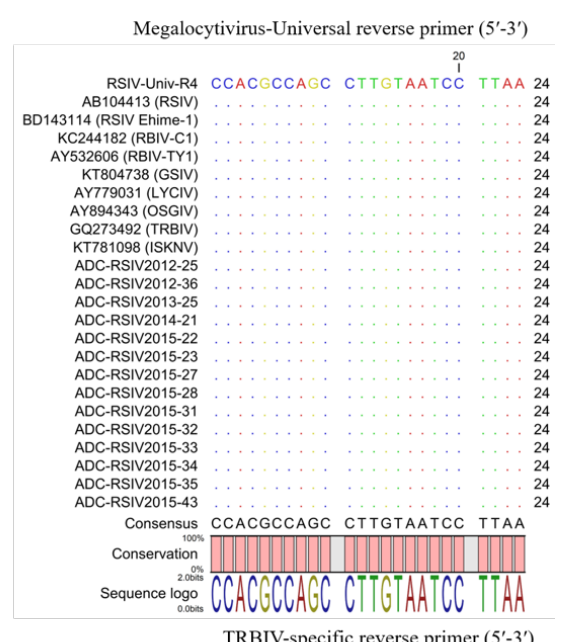

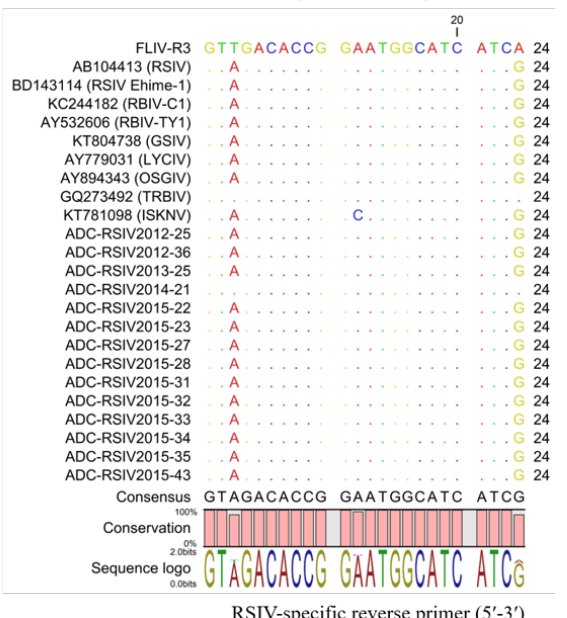

RSIV-specific reverse primer $\left(5^{\prime}-3^{\prime}\right)$

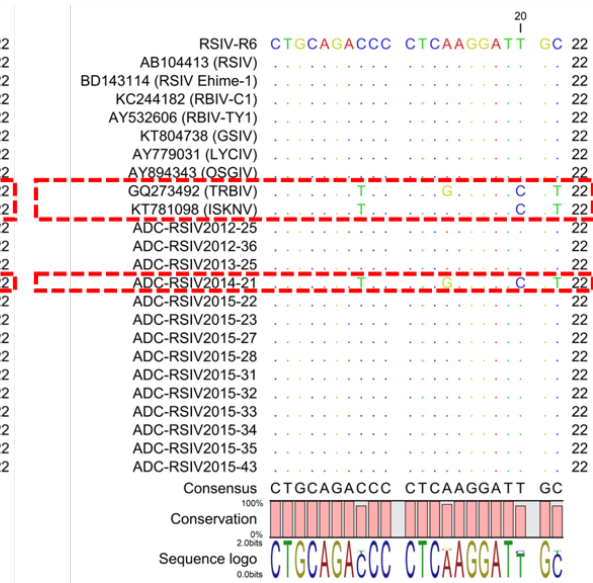

Figure 4 


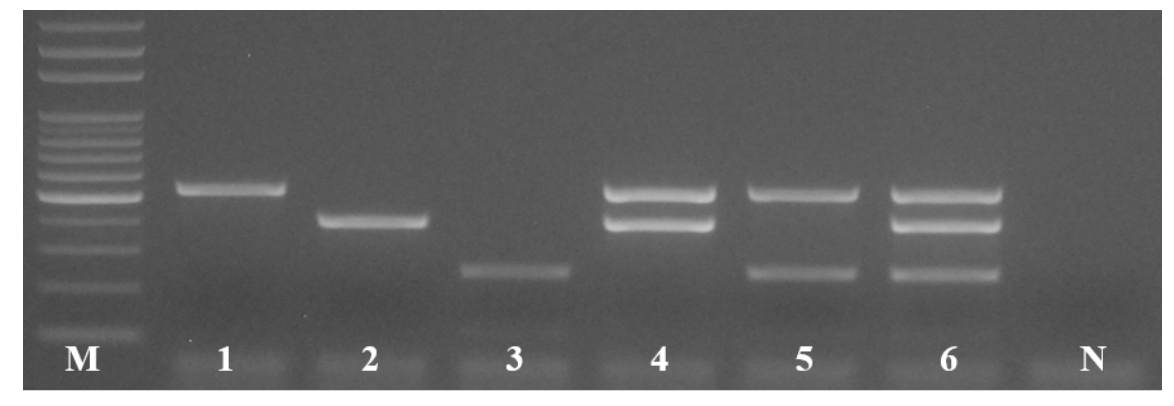

Figure 5 


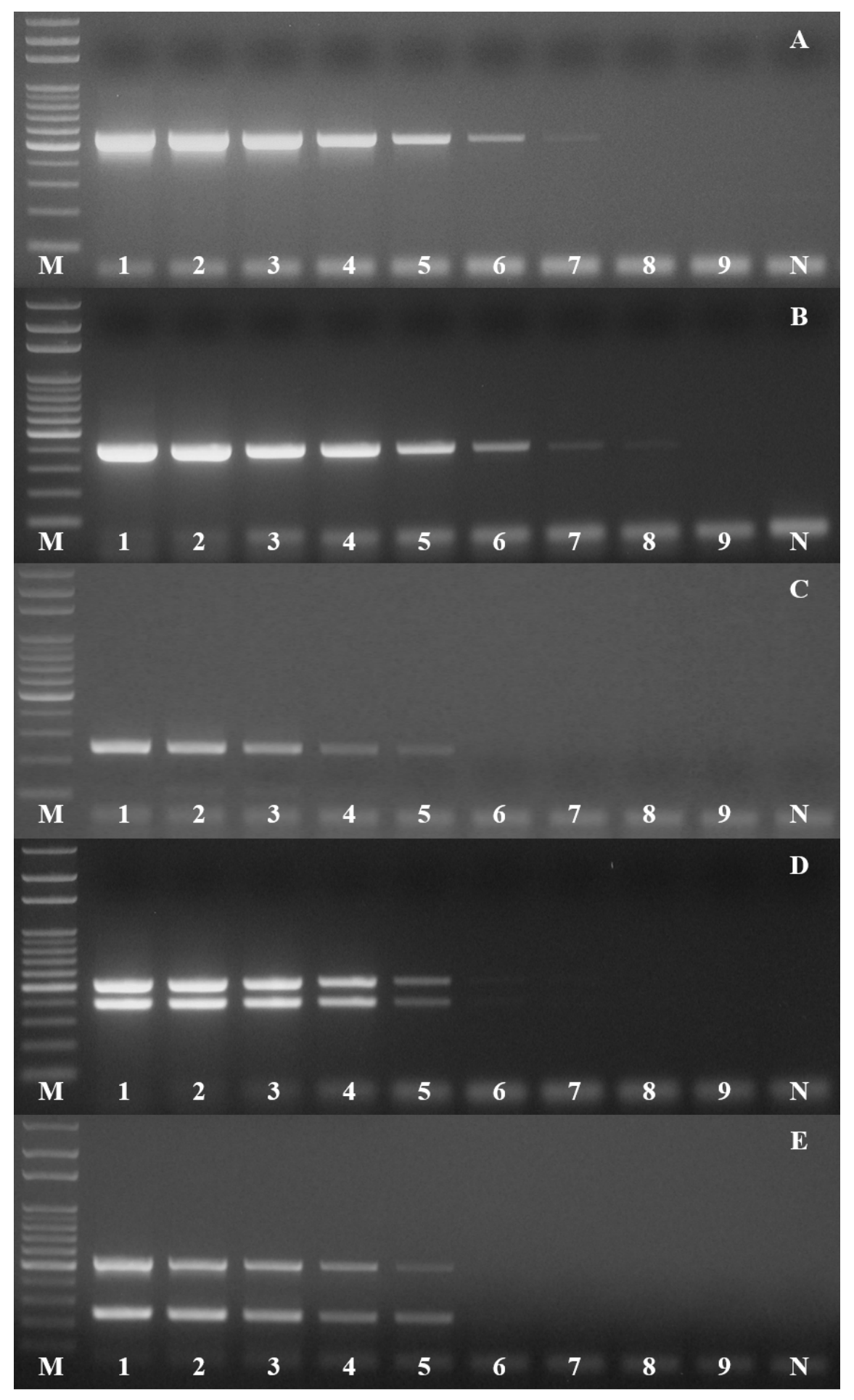

Figure 6 


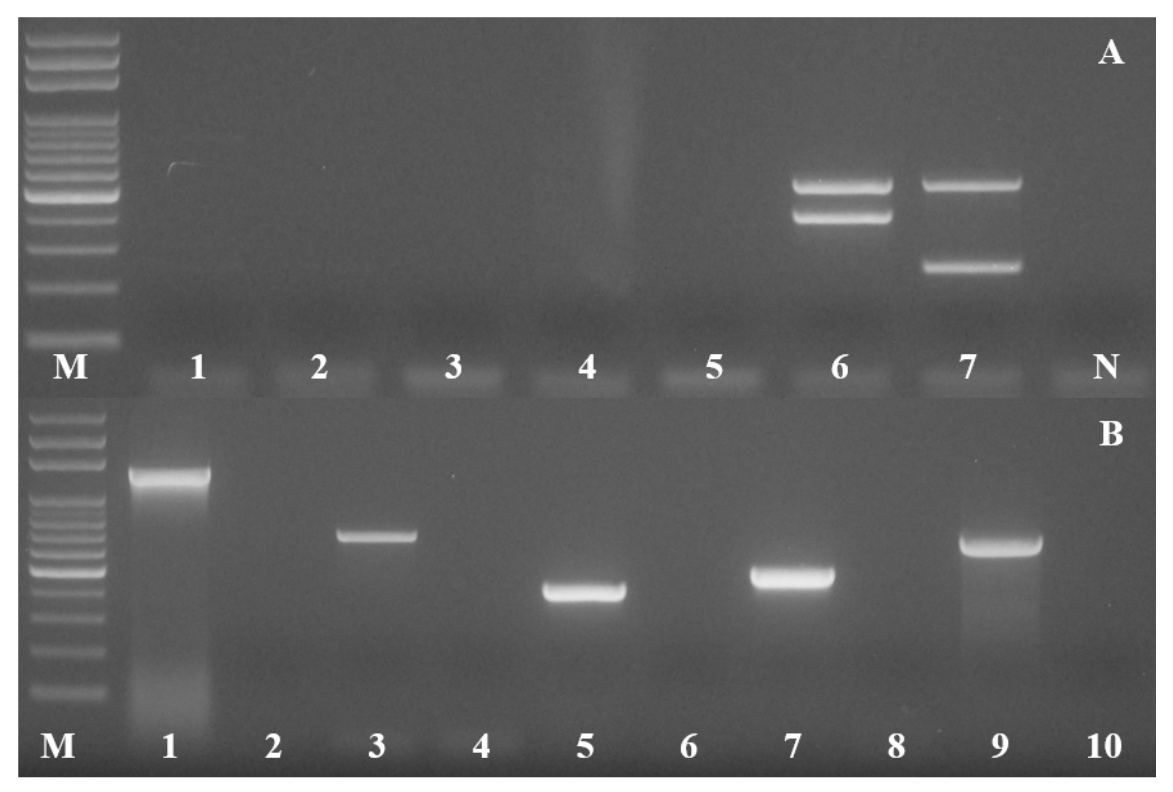

Figure 7

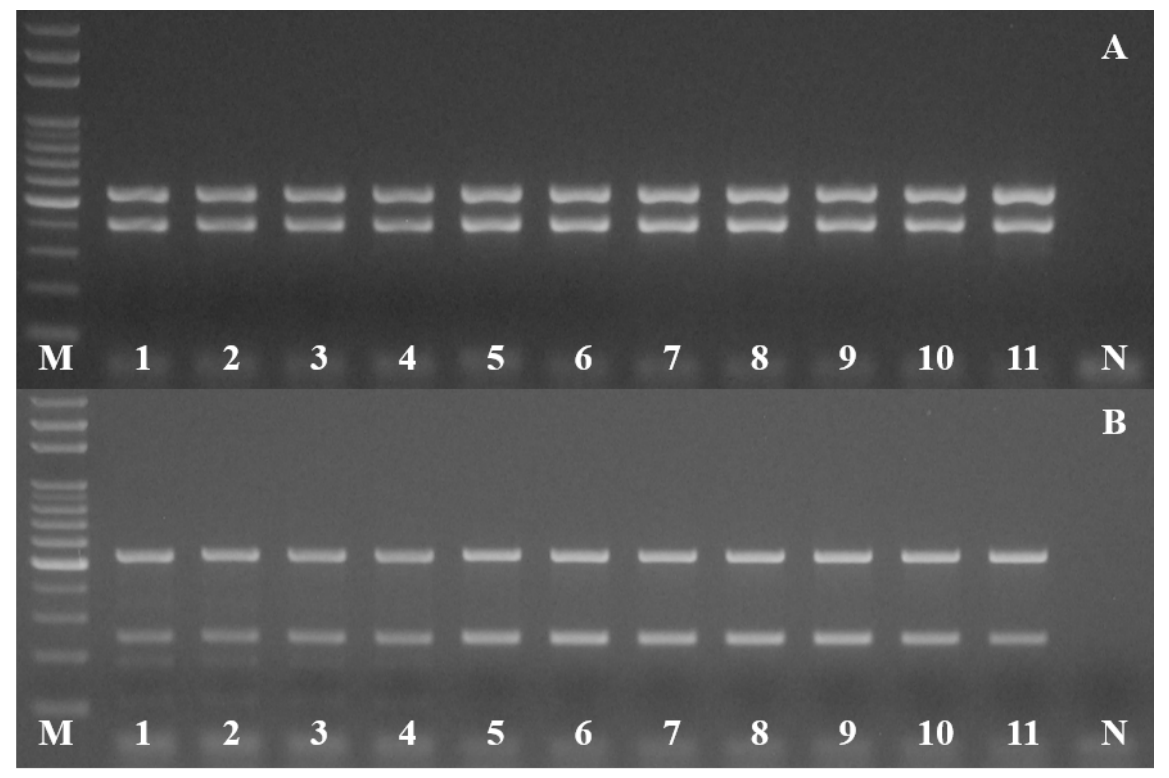

Figure 8 


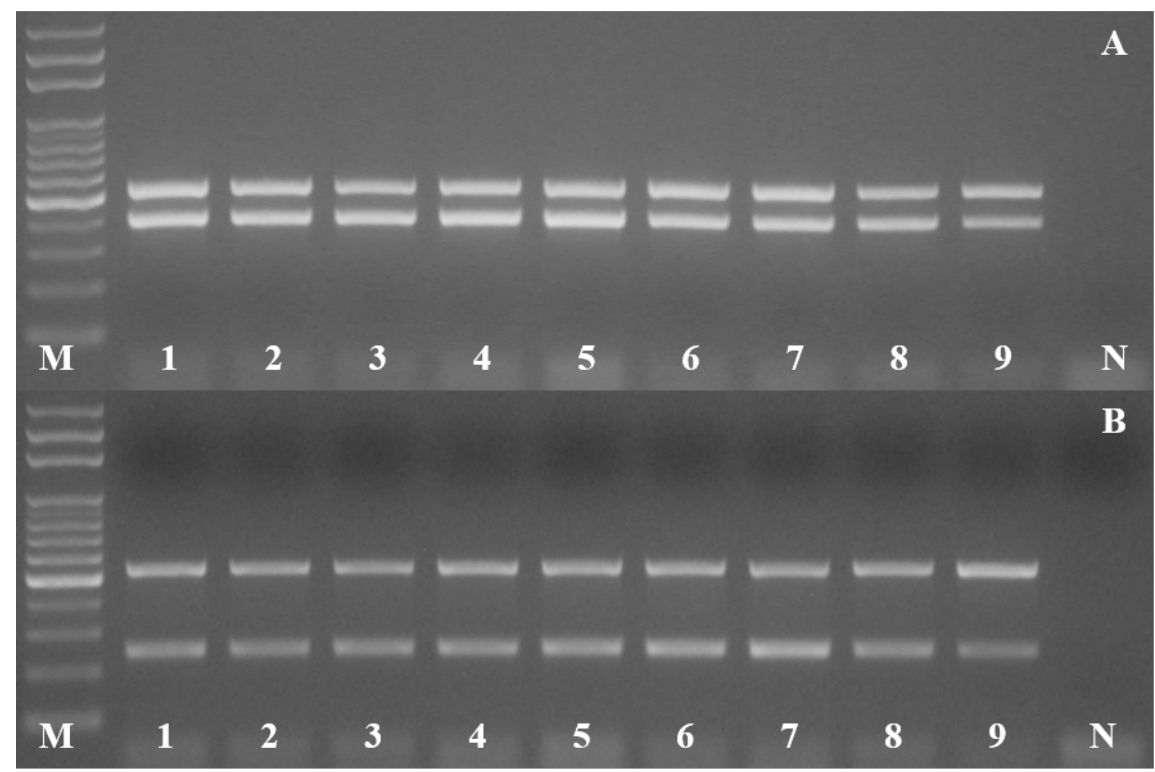

Figure 9

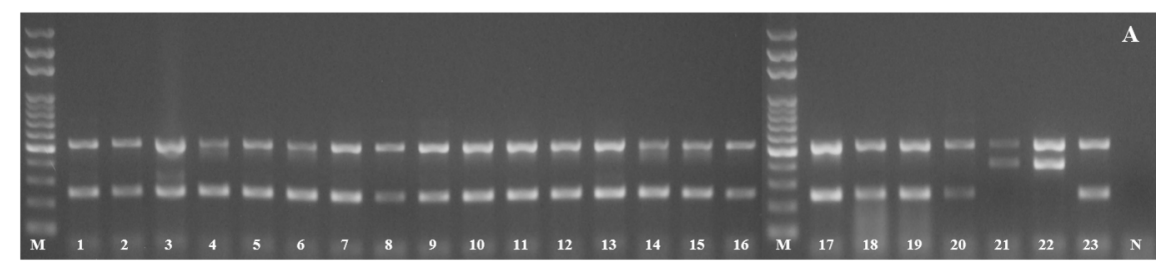

Table 1

\begin{tabular}{|c|c|c|c|c|c|c|c|}
\hline Isolate name & $\begin{array}{l}\text { Year of } \\
\text { isolation }\end{array}$ & $\begin{array}{l}\text { Geographic } \\
\text { origin }\end{array}$ & $\begin{array}{l}\text { Host } \\
\text { common } \\
\text { name (host } \\
\text { species) }\end{array}$ & Genotype & $\begin{array}{l}\text { Accession } \\
\text { number }\end{array}$ & $\begin{array}{l}\text { Accession } \\
\text { number }\end{array}$ & $\begin{array}{l}\text { Accession } \\
\text { number }\end{array}$ \\
\hline $\begin{array}{l}\text { ADC- } \\
\text { RSIV2012- } \\
23\end{array}$ & 2012 & Tongyeong & $\begin{array}{l}\text { Rock bream } \\
\text { (Opleg- } \\
\text { nathus } \\
\text { fasciatus) }\end{array}$ & RSIV & $\begin{array}{l}\text { ATPase } \\
\text { MT767078 }\end{array}$ & $\begin{array}{l}\text { DPO } \\
\text { MT767064 }\end{array}$ & $\begin{array}{l}\text { LRP } \\
\text { MT767092 }\end{array}$ \\
\hline $\begin{array}{l}\text { ADC- } \\
\text { RSIV2012- } \\
25^{*}\end{array}$ & 2012 & Tongyeong & $\begin{array}{l}\text { Red } \\
\text { seabream } \\
\text { (Pagrus } \\
\text { major })\end{array}$ & RSIV & MT767079 & MT767065 & MT767093 \\
\hline $\begin{array}{l}\text { ADC- } \\
\text { RSIV2012- } \\
36^{*}\end{array}$ & 2012 & Yeosu & $\begin{array}{l}\text { Rock bream } \\
\text { (Opleg- } \\
\text { nathus } \\
\text { fasciatus) }\end{array}$ & RSIV & MT767080 & MT767066 & MT767094 \\
\hline
\end{tabular}




\begin{tabular}{|c|c|c|c|c|c|c|c|}
\hline Isolate name & $\begin{array}{l}\text { Year of } \\
\text { isolation }\end{array}$ & $\begin{array}{l}\text { Geographic } \\
\text { origin }\end{array}$ & $\begin{array}{l}\text { Host } \\
\text { common } \\
\text { name (host } \\
\text { species) }\end{array}$ & Genotype & $\begin{array}{l}\text { Accession } \\
\text { number }\end{array}$ & $\begin{array}{l}\text { Accession } \\
\text { number }\end{array}$ & $\begin{array}{l}\text { Accession } \\
\text { number }\end{array}$ \\
\hline $\begin{array}{l}\text { ADC- } \\
\text { RSIV2013- } \\
18\end{array}$ & 2013 & Tongyeong & $\begin{array}{l}\text { Japanese sea } \\
\text { bass } \\
\text { (Lateolabrax } \\
\text { japonicus) }\end{array}$ & RSIV & MT767081 & MT767067 & MT767095 \\
\hline $\begin{array}{l}\text { ADC- } \\
\text { RSIV2013- } \\
19\end{array}$ & 2013 & Jeju & $\begin{array}{l}\text { Rock bream } \\
\text { (Opleg- } \\
\text { nathus } \\
\text { fasciatus) }\end{array}$ & RSIV & MT767082 & MT767068 & MT767096 \\
\hline $\begin{array}{l}\text { ADC- } \\
\text { RSIV2013- } \\
20\end{array}$ & 2013 & Yeosu & $\begin{array}{l}\text { Rock bream } \\
\text { (Opleg- } \\
\text { nathus } \\
\text { fasciatus) }\end{array}$ & RSIV & MT767083 & MT767069 & MT767097 \\
\hline $\begin{array}{l}\text { ADC- } \\
\text { RSIV2013- } \\
25^{*}\end{array}$ & 2013 & Yeosu & $\begin{array}{l}\text { Rock bream } \\
\text { (Opleg- } \\
\text { nathus } \\
\text { fasciatus) }\end{array}$ & RSIV & MT767084 & MT767070 & MT767098 \\
\hline $\begin{array}{l}\text { ADC- } \\
\text { RSIV2014- } \\
14\end{array}$ & 2014 & Sachun & $\begin{array}{l}\text { Flathead } \\
\text { grey mullet } \\
\text { (Mugil } \\
\text { cephalus) }\end{array}$ & RSIV & MT767085 & MT767071 & MT767099 \\
\hline $\begin{array}{l}\text { ADC- } \\
\text { RSIV2014- } \\
21^{*}\end{array}$ & 2014 & Jangheung & $\begin{array}{l}\text { Olive } \\
\text { flounder } \\
\text { (Par- } \\
\text { alichthys } \\
\text { olivaceus) }\end{array}$ & TRBIV & MT767086 & MT767072 & MT767100 \\
\hline $\begin{array}{l}\text { ADC- } \\
\text { RSIV2014- } \\
22\end{array}$ & 2014 & Yeosu & $\begin{array}{l}\text { Rock bream } \\
\text { (Opleg- } \\
\text { nathus } \\
\text { fasciatus) }\end{array}$ & RSIV & MT767087 & MT767073 & MT767101 \\
\hline $\begin{array}{l}\text { ADC- } \\
\text { RSIV2015- } \\
22^{*}\end{array}$ & 2015 & Yeosu & $\begin{array}{l}\text { Rock bream } \\
\text { (Opleg- } \\
\text { nathus } \\
\text { fasciatus) }\end{array}$ & RSIV & MT767088 & MT767074 & MT767102 \\
\hline $\begin{array}{l}\text { ADC- } \\
\text { RSIV2015- } \\
23^{*}\end{array}$ & 2015 & Yeosu & $\begin{array}{l}\text { Japanese sea } \\
\text { bass } \\
\text { (Lateolabrax } \\
\text { japonicus) }\end{array}$ & RSIV & MT767089 & MT767075 & MT767103 \\
\hline $\begin{array}{l}\text { ADC- } \\
\text { RSIV2015- } \\
27^{*}\end{array}$ & 2015 & Yeosu & $\begin{array}{l}\text { Rock bream } \\
\text { (Opleg- } \\
\text { nathus } \\
\text { fasciatus) }\end{array}$ & RSIV & MT767090 & MT767076 & MT767104 \\
\hline $\begin{array}{l}\text { ADC- } \\
\text { RSVI2015- } \\
28^{*}\end{array}$ & 2015 & Yeosu & $\begin{array}{l}\text { Rock bream } \\
\text { (Opleg- } \\
\text { nathus } \\
\text { fasciatus) }\end{array}$ & RSIV & MT767091 & MT767077 & MT767105 \\
\hline
\end{tabular}




\begin{tabular}{|c|c|c|c|c|c|c|c|}
\hline Isolate name & $\begin{array}{l}\text { Year of } \\
\text { isolation }\end{array}$ & $\begin{array}{l}\text { Geographic } \\
\text { origin }\end{array}$ & $\begin{array}{l}\text { Host } \\
\text { common } \\
\text { name (host } \\
\text { species) }\end{array}$ & Genotype & $\begin{array}{l}\text { Accession } \\
\text { number }\end{array}$ & $\begin{array}{l}\text { Accession } \\
\text { number }\end{array}$ & $\begin{array}{l}\text { Accession } \\
\text { number }\end{array}$ \\
\hline $\begin{array}{l}\text { ADC- } \\
\text { RSIV2015- } \\
31^{*}\end{array}$ & 2015 & Yeosu & $\begin{array}{l}\text { Rock bream } \\
\text { (Opleg- } \\
\text { nathus } \\
\text { fasciatus) }\end{array}$ & RSIV & MT767078 & MT767064 & MT767092 \\
\hline $\begin{array}{l}\text { ADC- } \\
\text { RSIV2015- } \\
32^{*}\end{array}$ & 2015 & Yeosu & $\begin{array}{l}\text { Rock bream } \\
\text { (Opleg- } \\
\text { nathus } \\
\text { fasciatus) }\end{array}$ & RSIV & MT767079 & MT767065 & MT767093 \\
\hline $\begin{array}{l}\text { ADC- } \\
\text { RSIV2015- } \\
33^{*}\end{array}$ & 2015 & Yeosu & $\begin{array}{l}\text { Rock bream } \\
\text { (Opleg- } \\
\text { nathus } \\
\text { fasciatus) }\end{array}$ & RSIV & MT767080 & MT767066 & MT767094 \\
\hline $\begin{array}{l}\text { ADC- } \\
\text { RSIV2015- } \\
34^{*}\end{array}$ & 2015 & Yeosu & $\begin{array}{l}\text { Rock bream } \\
\text { (Opleg- } \\
\text { nathus } \\
\text { fasciatus) }\end{array}$ & RSIV & MT767081 & MT767067 & MT767095 \\
\hline $\begin{array}{l}\text { ADC- } \\
\text { RSIV2015- } \\
35^{*}\end{array}$ & 2015 & Tongyeong & $\begin{array}{l}\text { Rock bream } \\
\text { (Opleg- } \\
\text { nathus } \\
\text { fasciatus) }\end{array}$ & RSIV & MT767082 & MT767068 & MT767096 \\
\hline $\begin{array}{l}\text { ADC- } \\
\text { RSIV2015- } \\
43^{*}\end{array}$ & 2015 & Namhae & $\begin{array}{l}\text { Rock bream } \\
\text { (Opleg- } \\
\text { nathus } \\
\text { fasciatus) }\end{array}$ & RSIV & MT767083 & MT767069 & MT767097 \\
\hline $\begin{array}{l}\text { ADC- } \\
\text { RSIV2017- } \\
66\end{array}$ & 2017 & Pohang & $\begin{array}{l}\text { Starry } \\
\text { flounder } \\
\text { (Platichthys } \\
\text { stellatus) }\end{array}$ & RSIV & MT767085 & MT767071 & MT767099 \\
\hline $\begin{array}{l}\text { ADC- } \\
\text { RSIV2018- } \\
89\end{array}$ & 2018 & Gijang & $\begin{array}{l}\text { Starry } \\
\text { flounder } \\
\text { (Platichthys } \\
\text { stellatus) }\end{array}$ & RSIV & MT767084 & MT767070 & MT767098 \\
\hline
\end{tabular}

*Used in sequence analysis.

Table 2

\begin{tabular}{|c|c|c|c|}
\hline Primer name & Purpose & Gene & Sequence $\left(5^{\prime}-3^{\prime}\right)$ \\
\hline 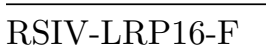 & Sequencing of LRP gene & LRP & TAAAGAGGTTATATCATCCAACACAACACT \\
\hline RSIV-LRP16-R & & & CCACAGTCAGCAACAGAAGAAGTAGCA \\
\hline RSIV-EGF-F & Sequencing of EGF gene & EGF & TCTCCTATCTCAAGCACAGTGAACATCTTT \\
\hline RSIV-EGF-R & & & CCATTGTTGGGGCACGGAC \\
\hline RSIV-DPO-F & Sequencing of DPO gene & DPO & CTTCAGCTTCAGGTTCACGCATGC \\
\hline RSIV-DPO-R & & & GTGATGAGTCTGCCATTGTTTTTATATAG \\
\hline RSIV-ATPase-F & Sequencing of ATPase gene & ATPase & ATGTTTGCCCCCTTACTGCCAATGTA \\
\hline RSIV-ATPase-R & & & CAGCAATCGGCTGAAGCAGC \\
\hline
\end{tabular}




\begin{tabular}{llll}
\hline Primer name & Purpose & Gene & Sequence (5'-3') \\
\hline RSIV-EGF-F (Turbot) & Sequencing of EGF gene in turbot & EGF & CGCGACACTAGCACCAACACG \\
RSIV-EGF-R (Turbot) & & & ACACTGTCCTACTGGGTTGTCGTC \\
RSIV 1-F (Turbot) & Sequencing of EGF gene in turbot & EGF & GTCTATCCGGAGTGTTTGAG \\
RSIV 1-R (Turbot) & & & GCACCAACACGTCTCCTATC \\
\hline
\end{tabular}

Table 3

\begin{tabular}{|c|c|c|c|c|}
\hline Primer name & Purpose & Gene & Sequence $\left(5^{\prime}-3{ }^{\prime}\right)$ & Amplicon lengt \\
\hline RSIV-1F-OIE & Detection of RSIV \& ISKNV & Pst I fragment & CTCAAACACTCTGGCTCATC & $570 \mathrm{bp}$ \\
\hline RSIV-1R-OIE & & & GCACCAACACATCTCCTATC & \\
\hline RSIV-4F-OIE & Detection of RSIV & $\mathrm{DPO}$ & CGGGGGCAATGACGACTACA & $568 \mathrm{bp}$ \\
\hline RSIV-4R-OIE & & & CCGCCTGTGCCTTTTCTGGA & \\
\hline Meg-Univ-F4 & Detection of RSIV & ATPase & AGGCCAACCACTTCTACAGCAAG & $534 \mathrm{bp}$ \\
\hline Meg-Univ-R4 & & & CCACGCCAGCCTTGTAATCCTTAA & \\
\hline FLIV-F5 & Detection of TRBIV & LRP & GCTGGCGATGGTGCTCTTGTG & $401 \mathrm{bp}$ \\
\hline FLIV-R3 & & & GTTGACACCGGAATGGCATCATCA & \\
\hline RSIV-F6 & Detection of RSIV & DPO & GGCTGTAAACGCCAGTGACACT & $245 \mathrm{bp}$ \\
\hline RSIV-R6 & & & CTGCAGACCCCTCAAGGATTGC & \\
\hline
\end{tabular}

